\title{
From Non-violent Protests to Suicide Bombing: Social Movement Theory Reflections on the Use of Suicide Violence in the Nigerian Boko Haram
}

\author{
Kingsley Ekene Amaechi \\ kingsleyokafor06@gmail.com
}

\begin{abstract}
This article uses the northern Nigerian-born Boko Haram to reflect on the development and use of suicide violence in Salafi-Islamist groups. Drawing on data from a combination of semi-structured interviews and a secondary analysis of previous research on the group, the article investigates how suicide bombing developed and became a significant strategy for goal attainment within the group. Rather than 'exceptionalise' suicide violence, the article analyses this element as part of a fluid and evolving spectrum of movement tactics that evolves as such groups try to achieve their goals within the particular socio-political environment in which they identify.
\end{abstract}

Keywords: Boko-Haram, Salafi-Islamist groups, Social Movement Theory, Suicide Violence, Violence

\section{Introduction}

In the wake of the recent use and justification of suicide violence by Salafi Islamist groups around the world, suicide violence has sadly become a strategy associated with Islam. I use the term 'Salafi-Islamist' here as a more precise ideological and religious term, distinct from other less radical Islamist groups in the recent discussions of Islamic religious groups. Following James Piscatori 
(2000:2), 'Islamists' refers to those 'Muslims who are committed to political action to implement what they regard as an Islamic agenda'. Hence, I call Salafi Islamist those organisations within Salafism ${ }^{1}$ who are committed to Salafist ideologies, and use these ideologies to propagate and implement what they regard as a Salafist or Islamic agenda within the context of the modern nationstate. Often the Islamist agendas intended here are inherently political, but not necessarily associated with political violence. They include a broad repertoire of social movement activism such as protests, campaigns, seminars, general da'wa (religious proselytising), preaching, partisan political involvements, rendering of social and welfare services, publications, political violence (suicide violence). Typical examples of such organisations include Egypt's Muslim Brothers, Al-Qaeda, Al-Qaeda in the Islamic Maghreb, and AlShabaab.

The last decade has probably seen an increase in the emergence of these groups, most of them going as far as using several forms of suicide violence as a strategy to achieve their goals within the political environment within which they operate (Juergensmeyer 2003; Hafez 2004; Hafez and Wiktorowicz 2004). Often these suicide attacks have featured the most barbaric forms of violence such as car bombs, airline suicide missions, indiscriminate driving into crowds, gun attacks, throat slitting of oneself in the public etc. In most cases, these groups reference ideologies and historical

${ }^{1}$ Salafism in general is actually quite a broad and expansive Islamic tradition. The vast majority of its adherents are peaceful - they are not violent extremists. The tradition is characterized by its sharp emphasis on theological purity and an identification with the practice of the religion's first 'devout ancestors' (the salafs). This tendency is reinforced by the belief of being entrusted with a mission to revive the original creed of these forebears of Islam, purportedly lost at some point in the history of Islam. Salafis, especially those of the Wahhabi orientation, believe that they constitute the historical embodiment of the 'saved sect' (al-firqa al-nājiya) mentioned in a famous statement attributed to the Prophet Muhammad, which they interpret in an exclusivist sense. Such an exclusivist attitude is directed not only towards Shiite beliefs, but also towards much, if not most, of the historical manifestations of Sunni religiosity and theological thought, which Salafis variously categorise as spurious (bid'a) or as outright unbelief (kufr). 
narratives within the Salafist tradition as the justifications from which this activism emanates (Wiktorowicz 2004).

Following this, many scholars have analysed the religious and theological justifications within Salafism as the single most important incentive for the motivation and justification of this element (Caschetta 2015; Onuoha 2015). For such scholars, the fact that these organisations subscribe to the ideologies, the traditions and the histories within the Salafi thought makes such groups very prone to adopt such radical strategy. Within such tradition, activists can appropriate not just the appropriate political identities and vengeful imperatives that make it easier for such self-sacrificial activism to be justified, but also the mores and the traditional symbols upon which such selfsacrificial activism is construed.

Other scholars on the other hand down play the role of Salafism, analysing instead other multiple elements such as the environmental, political and economic factors, which emphasise the rational choice of activists (Elster 2006), or psychological deviancy within Salafi Islamist groups (Walker 2016) or a combination of these factors as elements, which underlie the overall emergence of self-sacrifice within such groups (Comolli 2015; Esposito 2015; Juergensmeyer 2003). For most of these scholars, the real motivations behind suicide violence within Salafi-Islamist groups are in fact economic, social, and political, and not just religious. Hence, the adoption and the use of this suicide violence is only a means with which these activists respond to the culture of violence or frustrations and dissatisfaction, as the groups navigate the sociopolitical environments where they operate. From this perspective, suicide violence only provides the needed strategic tactical or symbolic means for the individuals and organisations to achieve certain goals within their political environments.

These explanations of suicide violence are valuable for understanding the conditions responsible for the evolution of this strategy; however, they offer restricted insight into the fluidity that characterise the evolution and proliferation of this strategy within such groups. Social movement inspired research shows that violent activisms in general within groups are often not simply a tactical choice or an ideological imperative that emanates from sociopolitical factors or religious beliefs. Instead, activists within the movement organisations move towards violent activism as a result of competing interpretations of their interests and identities within the movements' contexts (Gunning 2007:195-240; 2009:172; Gunning and Baron 2013: 1-60; Hafez 
2004: 37-60). The different forms violence takes (including suicide bombings) are often fuelled by diverse access to resources and the changing ideological and political attitudes towards violence and other types of protests and violence - what Sydney Tarrow (quoted in Gunning 2009:162) calls 'protests circles', which are in turn affected by state practices, not just towards the activists, but towards the society in which the activists identify.

The development of violence activism, and later suicide bombing in the Palestinian Hamas for example, evolved after many years of long standing internal dynamics and debates within the organisation in response to the continuous violent interactions between the organisation and the Israeli security forces (Gunning 2007:195-240; 2009: 172). Similarly, the development of the use of violence in the Algerian Islamic Army's (Groupe Islamique Arme, GIA) militancy also emerged after many years of long drawnout contestations between the original non-violent Bouyali Organisation and the Military-backed government, in response to the increasingly close down of the political systems in Algeria in the early 1990s. The particular form of violence the activism took (among which was suicide bombings) was influenced highly by the violent interaction between the group and the state that evolved as the group engaged with the state security services (Hafez 2004: 37-60). Thus, while the presence of certain elements such as ideology or environment may represent constituent conditions of a general violent reaction to intense peculiar conditions, analysing these elements (or a combination of two or more) does not explain how the strategy develops. To capture this we need to understand what 'informs' the decisions to adopt this kind of violence, rather than others as a strategy for goal attainment. In other words, what leads to shifts in repertoires of contentions, so that this form of radical violent strategy becomes an accepted instrument of collective action within the movement organisation. In a given environment, why would a Salafi Islamist group turn to this sophisticated and higher-risk kind of violent strategy, when there are other less low-risk available ones? Without understanding this fluidity, it is difficult to project a true picture of how and why this kind of activism would evolve within such a group. Movement organisations go through phases, during which violent activisms (including suicide violence) evolve (Gunning 2009:163). The better approach to understand this phenomenon is to have a more resolute empirical analysis that discusses under what conditions such groups turn to suicide violence as a strategy. So, the question is: under what conditions do such organisations adopt suicide 
violence? Under what conditions are such strategies used and justified within such groups? How do such conditions lead such groups to turn to a violent suicide strategy, rather than other ones?

With the above in mind, therefore, this article analyses the conditions under which suicide violence developed and is justified within Boko Haram (BH), a Salafi-Islamist group that operates in Nigeria (and more recently in Cameroun, Chad and Niger). Depending mostly on paradigms from social movement inspired research (Dela Porta 2009; Gunning 2009; Wiktorowicz 2004), which conceptualise all dynamics within movement organisations as fluid and responsive to conditions and changes within the context upon which such movements identify, I investigate how this strategy evolved and became a tool for goal attainment. Using this approach, the emphasis is not on any one particular condition, but on the interactions between such conditions; how these conditions influence each other to impact on the individual and group choices to advance the appeal for the adoption and development of this kind of strategy within the group. Within such a perspective, I will see violence as not just an ideological imperative or a result of environmental influence, but as the outcome of a dynamic social process - an aspect which emerges in interactions with other evolving repertoires of political opportunities within the social movement and in the environment in which the organisation operates.

\section{Empirical Materials for the Study}

The data for the study was collected through a mixture of semi-structured interviews and secondary analysis of previous research on the group. This is a part of field work in a $\mathrm{PhD}$ project about the role of Islam in the development and escalation of violence in the Nigerian $\mathrm{BH}$.

First, I have selected literature with explicit and competent ethnographic knowledge about the group and the area both during the time when the group evolved and at the time when the group developed the use of suicide violence. Some of the literature include Ja'far Mahmoud Adam, Mohammed Yusuf and Al-Muntada Islamic Trust: Reflections on the Genesis of the Boko-Haram Phenomenon in Nigeria (Brigaglia 2012); The Volatility of Salafi Political Theology, the War on Terror and the Genesis of Boko Haram (Brigaglia 2015); Boko-Haram, Nigeria's Islamist Insurgency (Comolli 2015); Violence in Nigeria, the Crisis of Religious Politics and Secular Ideologies (Falola 1998); Defining and Understanding the Religious Philosophy of 
Jihadi-Salafism and the Ideology of Boko Haram (Kassim, 2015), BokoHaram and the Evolving Salafi Jihadist threat in Nigeria (Onuoha 2014); Boko-Haram: Islamism, Politics, Security and the State in Nigeria (Perouse de Montclos 2014). This literature contains quality ethnographic data, which contextualises the evolution of the group and development of the group in north-eastern Nigeria, during the time the strategy evolved within the group. In addition, I have used a number of semi-structured interviews to extract relevant primary data from a number of individuals within the Nigerian security forces, politicians and a religious leader. All the individuals interviewed have either worked closely or had been engaged with $\mathrm{BH}$ at the time when the group emerged and when they first started to use suicide violence. In total, ten individuals were interviewed: one Salafist scholar, who was an imam in one of the Salafi mosques in Maiduguri when BH first emerged, two politicians representing some of the affected areas within the region, and seven members of the Nigerian Joint Task Force (JTF) and from the Nigerian Police. While the religious leaders, and the two politicians interviewed still work in the area where BH has its stronghold, only one among the seven security personnel interviewed still works in the area, the remaining six now work in other parts of the country.

The mixture of semi-structured interviews and secondary analysis of previous primary research was beneficial because it assisted the study both to have a more balanced understanding of the development of this element over time, and to contextualise the conditions that helped facilitate the development of the strategy. They also complemented each other. In situations where the literature was deficient, the interviews provided valuable additions to the insights into the conditions and the group's activities, which are not covered in the previous literature about the group.

\section{Contextualising the Emergence of Boko Haram (2002-2009)}

There is hardly a disagreement among recent research that what is today referred to as 'Boko Haram' could be traced to the activism of Mohammed Yusuf, a self-proclaimed Salafi cleric who worshiped at the Ndimi Mosque in Maiduguri, and the political situations in Northern Nigeria ${ }^{2}$ in the late 1990s

${ }^{2}$ Northern Nigeria forms part of the second tier of the two large geographical regions (the North and South) that make up Nigeria. These two regions are 
and early 2000s (Brigaglia 2012:35; Pérouse de Montclos 2015:35; Onuoha 2015:185). Up until 1999, the country was under military dictatorship, governed by successive military generals. The country only returned to a democratically civilian rule after the sudden death of the then military dictator Sani Abacha in 1998. Following his death, the country was temporarily governed by Abdusalami Abubakar, who later handed over power to the democratically elected government of Olusegun Obasanjo (1999). The dawn of democracy would usher-in a new and different kind of political opportunity for a new wave of sharia advocacy ${ }^{3}$, that would lay the foundation for the emergence of a group like $\mathrm{BH}$ in northern Nigeria.

At the forefront of this pro-sharia advocacy, interestingly, there was no organised Islamist network with a political vision. What the region had at the time was an extended separate network of mostly Salafi actors. Unlike other Islamic trends (mostly Sufism), the Salafi network was a relatively new trend in Nigeria (late 1970s). As rightly observed by Brigaglia (2015:182), the trend was primarily represented by the two partly overlapping networks of Izala (Jamā'at 'Izālat al-Bid'a wa-Iqāmat al-Sunna) and Ahlus Sunna. Izala, as a Salafi trend, was established in 1978 by the students of Abu Bakr Mahmud Gumi (d. 1992). The group's main goals were to promote and popularise Gumi's critique of the traditional religious scholars (which are for the most part Ash'ari and Sufi) and to encourage the 'eradication' of spurious practices (bid'a), a term of classical Islamic heresiography which Izala, following

subdivided into six 'geo-political zones', each comprising of three zones: the North Central; Northeast; Middle Belt in the North, and the Southwest; Southsouth and Southeast in the South. Politically, the country is also divided along these geographical lines, into thirty-six states (excluding Abuja, which is the federal capital territory). It uses a presidential system that is similar to that of the United States. Of these geographically divided states the three main ethnic groups, the Hausa (mainly in the Core North), Yoruba (Southwest) and Igbo (Southeast), form the majority of the population. While Christianity is dominant in the Southeast and South-South areas, Islam is the dominant religion in the Core North and the Northeast. The Southwest and the Middle Belt have a mixed population of Muslims and Christians.

${ }^{3}$ The dawn of democracy opened up opportunity for many activists group to start to openly canvas for the implementation of sharia law for the Muslim majority states within the region. 
standard Wahhabi texts, liberally applies to most Sufi practices (Brigaglia 2015:182). Ahlus Sunna, on the other hand, emerged later after Izala, around a generation of younger Nigerian Salafis, many of whom had studied at the Islamic University in Medina (Saudi Arabia). The adherents of Ahnus Sunna often boast of a more robust grasp of the Wahhabi theology than their Izala counterparts, as well as a closer link with the global network of the students of the Saudi Arabia-based Salafi religious establishment. Although with little doctrinal variation, these two traditions represented the Salafi trend at the time BH emerged.

Yusuf, the would-be founder of $\mathrm{BH}$ was a product of these two traditions. Before becoming the spiritual leader of $\mathrm{BH}$, Yusuf was known to be a follower and a prominent and charismatic figure within both Ahnus Sunna and the Izala movement. At the dawn of sharia advocacy in the region, he had travelled to different parts of the region, preaching and representing the Ahnus sunna in several TV debates. By 2002, he had also become a prominent figure within the Ndimi mosque, one of the main Izala mosques within the region, rising to the position of the leader of the youth wing within the mosque. At some point he was known to have been considered as one of the most promising upcoming leaders in the Ahnus Sunna circle by Ja'far Adamu ${ }^{4}$, a renowned and charismatic leader within the Izala movement in the region. The relationship between the two men had grown when Adamu started preaching regularly in Maiduguri. But everything would change in 2002, when the former fell out with the Ahnus Sunna and Salafist leadership in the region.

Two main doctrinal issues have been identified as the main cause of the rift between Yusuf and the old leadership of Ahnus Sunna and Izala: first, Yusuf's rejection and condemnation of Western democracy, and second, his condemnation of participation and employment in the Nigerian government ${ }^{5}$. For Yusuf, democracy, as practiced particularly in Nigeria is a form of shirk (worship of an object other than God), which is inimical to Islamic lifestyles. Hence, such practices should be religiously forbidden to all Muslims, in exchange for a radical sharia system (Brigaglia 2015:175; Walker 2016:144). Izala and the old leadership of the Ahnus Sunna similarly believe in the

${ }^{4}$ An interview with an Izala imam, who worked closely with Yusuf at the Ndimi Mosque.

${ }^{5}$ An interview with an Izala imam and a high ranking police officer that worked in Maiduguri from 2001 to 2007. 
establishment of a 'true sharia law'. However, they have a very different approach on how to implement it. Rather than a radical path, they believe that the most effective approach is to work within the existing system pending the right time when the system would become desirable for the state to adopt such a sharia system (Brigaglia 2015:182). They also have a subtle approach to issues like Western education. Rather than reject it, they believe that Muslims should in fact acquire it, if they are to enhance their political influence in a place like northern Nigeria (Harnischfeger 2015:38). In their estimation, it is only when they are in such positions, that they (Muslims) have the possibility to implement the kind of change that is needed in a country like Nigeria ${ }^{6}$.

Some of the recent literature on the group have related this doctrinal distinction between Yusuf and the Ahnus Sunna to the two opposing discourses of a more violent 'Salafi jihadist' and less violent 'Salafi jihadist' in the general Salafist discourse. In unpacking both sides' religious arguments, an anonymous article in a 2012 issue of the Journal of Religion in Africa holds that both arguments represent what can be regarded as 'Salafi radicalism' and 'Salafi counter-radicalism'. Although both sides participated in the Salafi tradition, and both agreed on the desirability of a struggle to establish an 'Islamic' form of government, Yusuf's answer to the question of how Muslims should establish the desired government according to him, led him 'toward radicalism and violent confrontation with the Nigerian government ${ }^{\text {'. In }}$ contrast, the leadership of Ahlus Sunna, he concludes, followed the non-radical path of tactical acceptance of the necessity of working within the non-Islamic government in order to achieve incremental improvement with the already existing government (albeit a Kafir one), pending the establishment of an Islamic government.

Two very recent works by Abdulbassit Kassim (2015) and Alex Thurston (2016) refer to it in similar terms. Kassim, particularly, points out that the debates between Boko Haram and Ahlus Sunna in Nigeria are the local manifestation of a tension existing between global 'quietist' and 'jihadi' Salafi trends. The terms are reminiscent of the model articulated by the social movement scholar Quintan Wiktorowicz (2006). In Thurston's definition, borrowing from Wiktorowicz (2006: 208), the quietist Salafis (which he

${ }^{6}$ Interview with two Sunni clerics, who are also politicians representing some of the states in the region.

${ }^{7}$ Anonymous Article 2012. 
preferred to call 'purists') are defined as those who focus on 'nonviolent methods of propagation, purification, and education'. They discourage their followers from political activism, sticking to the classical, Sunni principle, which entails total obedience to the Muslim ruler. The second trend, according to him, on the other hand calls for 'violence and revolution' to overthrow the governments of their countries (Wiktorowicz 2006: 208). The militant call of a jihadi like Yusuf - Kassim and Thurston therefore conclude - was based on a more rigid application of the principle of takfir (excommunication) of the Muslim ruler who rules by other than God's revealed law (al-hukm bi-ghayr $m \bar{a}$ anzala Allāh), as well as on the basis of the associated principle of al-wala ${ }^{\prime}$ $w a$ 'l-barā' (loyalty to Islam and disavowal of everything else), which implies that a deficiency shown in one's loyalty to the laws of Islam or in the disavowal of non-Islamic systems constitutes, by itself, an act of unbelief (kufr), putting the one (in this case, the Muslim ruler) who commits it, out of the fold of Islam.

Now, in the context of post-sharia implementation in the region (Northern Nigeria $)^{8}$, it is easy to see how these doctrinal differences would lay the foundation upon which a more radical $\mathrm{BH}$ would emerge. First, the implementation of the sharia law simply did not necessitate a secure and corrupt free environment, as the Salafi activists had hoped. Second, in creating the sharia committees that would advise the governments of the various 'sharia states', the political elites had ended up recruiting many of the traditional, prevalently Sufi scholars, who still constituted, in many states, the majority of the clerical class at the grass-root level. Paradoxically, the sharia reforms that

${ }^{8}$ By the beginning of 2002, all the 12 state governments in the region had already adopted sharia as their states' binding penal code. But the sharia law by no means achieved what it was intended to achieve, at least from the Salafist estimation. The introduction of the new penal codes had elicited two main popular dreams within the region - what Brigaglia (2015: 182) would refer to as 'Islamist and salafist utopia'. The first is a political dream based on the assumption that the implementation of the new sharia-inspired penal codes would lead to the creation of a perfect, united, secure and corruption-free Islamic society. The second was a puritanical Salafist religious utopia, based on the assumption that the sharia reforms would ultimately empower the Salafi movement, providing it with new tools to enforce its creed and to implement 'correct' religious practices (Brigaglia 2015:182). None of the two aspirations was fully realised in practice. 
had been the trademark of Izala and Ahlus Sunna, ended up empowering the Sufis and forced the Salafists to accept a doctrinal compromise, the very canon they had always wanted to correct. This would make many more Salafi activists to gradually become very disenchanted with the Salafist leadership, whom Yusuf soon started to accuse as colluding with the government in 'not advancing the cause of Islam'?

Soon, Yusuf would also begin to reject the Islamic courts operating the sharia-inspired codes launched by the governments of the Muslim states of the north. As he consistently intensified his criticisms of the traditional Izala and Ahnus Sunna leadership, and other Islamic establishments within the region, he gained a lot more popularity within the mainly Salafi like-minded youths. By 2002, Yusuf would lead most of these youths, most of whom had worshiped at the Ndimi mosque in Maiduguri, to relocate to a place called Kanama ${ }^{10}$, to establish their own group. Here, they took an official name Jama'atu Ahlis Sunna Lidda'awatiwal-jihad (the People Committed to the Propagation of the Prophet's Teachings and Jihad), still in identification with what they regard as the "real Ahnus sunna" ${ }^{11}$. The seclusion to this remote place was according to an Izala cleric, in conformity with the Islamic notion of Hijra (a belief that Muslims should aspire to establish a proper Islamic community in a more secluded community, in identification with Mohammed's withdrawal from Mecca to Medina in the earliest days of Islam). Appalled with what they considered to be a high level of compromise of their Salafi canon, the group hoped to establish their own true Islamic community. From there, they intended to continue to persuade the government to establish a correct state, which they believe is the only place to attain a true Islamic life style.

Unfortunately, this advocacy was from the beginning doomed to fail. The fact that the group had issues with the old leadership of Ahnus Sunna and Izala means that the possibility of achieving this goal is far from being unrealistic. First, most of the institutions entrusted with the implementation of the sharia law within the region were dominated by people within the traditional Salafist and Ahnus sunna network. And most of these people are the same people who have issues with Yusuf and his followers. The Hisba board for example, the most prominent body entrusted with the implementation of

\footnotetext{
${ }^{9}$ Interview with an Izala imam.

${ }^{10}$ Kanama is a remote village close to the Nigerian border with Niger.

${ }^{11}$ Interview with an Izala imam.
} 
Islamic morality in public life and sharia, had Ja'far Mahmoud Adamu as one of its leaders (Brigaglia 2012: 38). Like Yusuf, such people had also been at the forefront of the advocacy and campaigns for the adoption of sharia law at the dawn of democracy in 1999. Thus, being in logger-heads with such individuals was tantamount to no or little access to the state's political institutions within the region. This means that the chance of legitimately achieving the kind of change the group was agitating for through dialogue, was almost non-existent.

On the federal government level, the case is even worse. Not only did the group not have 'friends' in the corridors of power, there were also no 'political will' from the Presidency to implement such a religious radical penal code. The existence of collusion between some Nigerian politicians and the $\mathrm{BH}$ founder ${ }^{12}$ at the time of the group's formation should not be misinterpreted as a corporation to aid $\mathrm{BH}$ to achieve such a political mission. On the contrary, most Northern politicians were never believers in the Salafi or BH message ${ }^{13}$. Most of them including the then Nigerian President Musa Yaradua (20072010), who won the Presidential election on the back of his northern regional and Islamic identity, never believed in the $\mathrm{BH}$ message. Such political gesture was only part of a political tool for them to win votes and re-elections among massive rural electorates, some who felt for the utopic dreams Yusuf and his group had promised during the sharia law advocacy. Like the other twelve governors within the region, the political imperative of having such an Islamic political identity at the centre of state governments was precisely because it consolidated their positions as sharing in the dreams of the electorates, as well as being political custodians and protectors of the region's Islamic identity

${ }^{12}$ The involvement of a number of northern politicians during the early stages of Boko Haram's genesis is undisputable, as shown by the case of former Borno state governor Ali Modu Sheriff. Sheriff is believed to have provided some support to the group during its formative period, and he famously appointed Buji Foi, a collaborator of Boko Haram's original leader Muhammad Yusuf, as the state's Commissioner for Religious Affairs in state. But this was only on the local state level.

${ }^{13}$ Two separate interviews with two Sunni politicians representing two of the political constituencies in the North East, and from two security officials that previously worked in Maiduguri confirmed how unrealistic politicians from the region believed $\mathrm{BH}$ sharia advocacy was. 
(Harnischfeger 2015:34-35). This being the case, the possibility of imposing such radical change from the Nigerian federal government was never going to happen. This means, it was almost impossible to see the possibility of Yusuf and his group at this time to legitimately achieve the kind of changes they advocated for. Consequently, the disposition towards other radical means like violent rhetoric and contentions, became more appealing as an appropriate medium to be heard and taken serious.

Soon the group would start to tune up their anti-state rhetoric. Some of the previous research depicts how it was at this time (2008) that the group began to tune up their jihadic rhetoric against the Nigerian state (Williams \& Guttschuss 2012:31-32). In some occasions, the group threatened to depose the Nigerian government. On many occasions, Yusuf and some of the group's leadership were arrested (Smith 2015: 56). Twice Yusuf was charged, but his prosecution never went forward ${ }^{14}$. In late 2008, the Borno state government banned Yusuf and his then deputy Abubakar Shekau from preaching in public (Williams and Guttschuss 2012:32). But as the group's goal of changing the sharia politics remain unachieved, all these pushed the group into becoming more hardened and inclined toward violent tendencies. Having no formal access to legitimate political institutions and being unable to influence the kind of change they hoped for, violence rhetoric increased and became more appealing as a viable option for the group to achieve their goal.

\section{Violence as a Strategy for Goal Attainment}

Despite the violent disposition that came from the group's Salafist doctrinal ideology, and the group's conflictual interaction with the old leadership of Ahnus Sunna and the Izala, BH never really officially adopted violence as a strategy for goal attainment until 2009. This strategy finally officially evolved at the dawn of more political opportunities as the group operated within the region. This is where I disagree with some of the previous research on the group (Brigaglia 2015; Thurston, 2016), who argue that the group's official adoption of violence began long before 2009. Brigaglia particularly believes that several cases of violence and an incident at Kanama in 2003, where BH was involved in a violent confrontation with the police, were pure

${ }^{14}$ Interview with one of the security personnel, who worked in the region and had followed BH developments closely. 
manifestations of the group's ability to act out on their already prepared violent strategy, rather than a mere banal confrontation between the group and the local state security officials (Brigaglia 2015:195). For him, by the time of establishment of the Kanama project in 2003, the group had already moved to Salafi-Jihadi positions. The Kanama camp thus was for him, an 'outpost' of the mainstream Salafi mission, and an Al-Qaeda training camp, established in collaboration with the older Salafist establishments. Implicitly, violence was bound to happen, it was a matter of when.

I find this assumption very inexact. First, this account is simply inconsistent with most available accounts of the Kanama incident ${ }^{15}$. Up until this day, Yusuf's group or its recent incarnation never officially claimed responsibility of the violent incidents that happened before 2009 (except the Kanama incident). On the Kanama case, most reliable reports ${ }^{16}$ indicate that the incident was a simple dispute between members of the group and some villagers about fishing rights, and escalated when police tried to meddle in the peace process (Comoli 2015; Walker 2016). Enraged by what they felt was unfair treatment by the local police, the Kanama $\mathrm{BH}$ activists attacked the local police stations in the coming days, over-powering the local police, and cateredaway with most of their local ammunitions. In retaliation, the local police descended on the group with full force. As many as seventy members of the group were killed, including Mohammad Ali, one of the prominent deputies of Yusuf. Yusuf, as the leader of the group, was declared wanted. To avoid prosecution, Yusuf fled to Saudi Arabia. Yusuf only returned to Nigeria through the assistance of Adamu Dibal, the former deputy governor of Borno state (Williams \& Guttschuss 2012: 30). In his own words, Yusuf at this time admits that 'even though I believe that an Islamic system of government should be established in Nigeria and if possible all over the world, it has to be through dialogue and not violence' (Williams \& Guttschuss 2012:32). This was not a group with the sophisticated military training from Al-Qaeda.

Secondly, I find it too presumptuous to conclude that the Kanama project was an Al-Qaeda project when there is no serious evidence to confirm this. If BH (from the Kanama camp) had been an Al-Qaeda military camp as some literature conclude, I do not understand why the group did not unleash

${ }^{15}$ Most of the security officials I spoke to disagree that Kanama was an established Al-Qaeda camp.

${ }^{16}$ Separate interviews with security officials. 
and start using some of the sophisticated violent strategies that had already been developed within their international sponsors (Al-Qaeda). They would not have to wait for an encounter or confrontation with the villagers and the local Kanama Police before they would start using a violent strategy, since they have already developed violent jihadist ideologies. Yes, the group's beliefs and Salafist jihadist ideology had disposed the group for a violent strategy, but this strategy was not set in motion until these were interpreted within some political opportunities within the contexts of the group's operation. Groups often act and adopt certain strategies when there are political opportunities to do so. Without such opportunities, such strategies remain only ideas.

The June 2009 incidents when the group finally adopted suicide bombing illustrate this case particularly. The problem began in Maiduguri when local police and some participants in a $\mathrm{BH}$ funeral procession clashed because of some of the members of the organisation's refusal to wear motorcycle helmets. Having refused to cooperate and abide to the road safety rules of using a personal protective helmet while riding on the high way, altercations ensued between the people and the police. In the subsequent days Yusuf demanded justice and threatened that he would take revenge on the Nigerian government, if they do not apologise and make reparations for what they had done (Comolli 2015: 54). When nothing of such came, Yusuf would start preparing seriously to attack the Nigerian security forces, with locally made ammunitions that were available to the group at that time.

To concretise this strategy (violence), Yusuf had to construe violent retaliations on the security forces as a religious moral duty that demanded action. 'We are starting a violent jihad in Nigeria which no force on earth can stop', Yusuf would tell his followers this time. 'The aim is to revenge the death of our brothers ... to Islamize Nigeria, to propagate the name of Allah and to liberate ourselves and our religion from the hands of this infidels ... It is the duty of every Muslim to join in this jihad, ... to achieve what Allah wants from us ${ }^{\prime 17}$. Under this kind of framing, the group's intended violent retaliation becomes an appropriate tool imperative on Yusuf's followers to fight the Nigerian security officials. It was during this time that one of Yusuf's followers accidentally blew himself up, while making a local bomb. Yusuf immediately called him a martyr (Williams \& Guttschuss 2012, 31), taking his framing

17 Yusuf's audio tape, given to me during my interview with one of the Nigerian security officials. 
further to encourage its members to also see anyone of his followers who dies in the cause of this fight as a holy warrior.

On the part of the Nigerian government, the group had to be stopped at all cost ${ }^{18}$. Hence, in the next few days, the Nigerian security forces launched an all-out attack on Yusuf and his group. Unfortunately, what the administration had hoped would be a ceremonial exercise turned highly violent. Armed with locally made guns, bows and arrows, the group fought back the security forces (Williams \& Guttschuss 2012: 34). However, because the group lacked experience ${ }^{19}$ and the fact that their locally made weapons were no match to the automatic guns and grenades of the Nigerian security forces who had now been reinforced from the federal government, they could not withstand the security forces for long. After a few days, the group was crushed. About 700 members of the organisation, including Yusuf, were killed (Brigaglia 2012:35). Other surviving members of the group went underground, putting an end to the violence within the group until January 2010 when the organisation re-emerged.

It is important to understand that $\mathrm{BH}$ at this time, was no longer a tiny number of youths that had operated in Kanama. Different from the Kanama group, the group at this time had more resources in terms of number of adherents that are scattered in the many parts of the country ${ }^{20}$. Yusuf had also

${ }^{18}$ Interview from a member of the Nigerian Joint Task Force, tasked with policing $\mathrm{BH}$.

${ }^{19}$ Interview from a member of the Nigerian Joint Task Force.

${ }^{20}$ Some of my informants, particularly, two politicians that represent some of the areas where $\mathrm{BH}$ operated in 2009 confirmed to me how BH had become a very formidable group as at the time of the group's confrontation with the Nigerian security forces in 2009. They explained that when Yusuf returned to the country in 2004, he quickly started the process of rebuilding the group. According to them what was important to him at that time was to re-build the organisation from the ruins of the 2003 crackdown. First, he changed the group's name officially to Jama'atuAhlisSunnLidda'awatiwal-jihad (the People Committed to the Propagation of the Prophet's Teachings and Jihad). Secondly, he relocated the group's main base from Kanama to Maiduguri, establishing a mosque in a land given to him from one of his wife's family. From there, starting to source for followers, making and releasing DVDs, audio cassettes and pamphlets, he tried to spread the group's new message. He and 
the advantage of an existing social organisational network from both his mosque and other similar loyal cells around the region ${ }^{21}$. Within the physical structure of such institutions, he had a religio-spatial structure for mobilisation. Several of my informants recount how, at this stage, Yusuf would gather his followers, send tapes with lessons and sermons, give instructions, distribute pamphlets, propagate and discuss the group's line of actions ${ }^{22}$. On the social level, this network also meant that most of his members and potential recruits had already existing social bonds - bonds which developed over time after some years of close acquaintance with one another. This kind of bonding made it easier for him to mobilise and sustain this strategy in the face of an extremely tense situation.

The adoption of this strategy at this time highlights the significance of availability of resources and political opportunities in the development of this strategy. Obviously, movement organisations are sensitive towards the availability of resources and evolution of political opportunities within the environments where they operate (Della Porta 2009:10; Hafez and Wiktorowicz 2004: 61-88). Violent confrontations with state authorities can create enabling political opportunities for movement organisations to act. However, without the corresponding resources (in the form of ideological framings, the financial resources for the ammunitions, social networks) groups may find it difficult to act even amidst these vast political opportunities. These resources determine both the form and the intensity of any strategy that evolves within movement groups. The availability of the group's Salafist ideology and the vast network of followers in Yusuf's case, made it possible that Yusuf and his group could develop the use of a violent strategy when the political opportunities arose from the state's brutal arrests and repressions. Under such

others within the group's leadership were also involved in dawah (proselytization) campaigns in different states within the region. By 2009, the group had branches in some of the states and all the major cities in the region. ${ }^{21}$ By the time of these developments, Yusuf already had his own new mosque. When Yusuf returned from Saudi Arabia, he relocated the group's base back to Maiduguri. There, he set-up a new mosque in the center of the city, which he named Ibn Taimiyyah Masjid. This was in a land owned by his father inlaw, Baba Fugu Mohammed.

22 Separate interviews from different members of the Nigerian security officials. 
situations, adopting a violent strategy easily becomes a legitimate and unique defence asset for such movement organisations to defend itself.

\section{Linking Resources and the Organisational Dynamics to the Development and Use of Suicide Bombing in BH (2010-2017)}

In the last seven years (2010-2017) $\mathrm{BH}$ has grown to an organisation which now uses different forms of violence strategically to attack the different segments of the Nigerian society. From using locally made knives, bows and machetes, the group has now graduated to the use of different advanced forms of attack, using sophisticated kinds of weapons, such as AK 47s, rocket grenades, car suicide bombings, body strapped suicide bombs, etc. Under the leadership of Shekau, the group had consistently used these advanced methods to attack state institutions, international institutions, churches, mosques, media houses, security personnel, religious leaders, politicians and ordinary civilians both within and outside the region. In 2014, the group changed its tactics from just guerrilla attacks to capturing cities such as Gwoza (August 2014), Bama (September 2014), and Mubi (September 2014), and uniting them with the areas around the already dominated sambisa forest, as part of an utopic unofficial Jihadist Islamic caliphate.

However, in the last two years, all these and other major urban centers captured by $\mathrm{BH}$ have been liberated. By the spring of 2015, the Nigerian security forces have been able to dismantle most of the training camps that Boko Haram had run in the Sambisa forest since. This has resulted in the de facto demise of the short-lived, unofficial Jihadist caliphate that the Boko Haram leaders had declared in August 2014. Still active unfortunately, Boko Haram have responded with a new campaign of violent attacks that have targeted the major urban centers of the states of Borno and Yobe (where the movement had originally started) as well as outside the country to Northern Cameroun, Chad and Niger Republic, often with a wave of sophisticated weapons and suicidal methods with kids and under-aged girls.

The first suicide bombing from the group occurred in June 2011, when the group attacked the Nigerian Police Chief at the Police headquarters in Abuja. Carefully planned, in the morning of July $16^{\text {th }} 2011$, a 37 years old member of the group, Mohammed Manga, followed the Nigeria's police chief's convoy into the police Headquarters, and detonated his big explosives 
as they entered the garage gate. Both the suicide bomber and other six police men standing nearby were killed at the spot. It was by sheer stroke of luck that the police Chief escaped the attack unharmed. What $\mathrm{BH}$ missed in the Police headquarters attack, they perfected at the UN building. On August 26 ${ }^{\text {th }} 2011$, Mohammad Abul Barra (27), another Boko Haram militant, allegedly drove his Honda Accord car into the UN building, ramming it into the two entrance gates, and unto the lobby of the main building, before detonating his car bomb. Only few pieces of the driver were found, some hours after the attack. In the last five years, the group has perfected this strategy and has used it to carry out uncountable attacks which have killed scores of civilians and security forces within the areas, where the group now operates. Once this strategy has been chosen, it has been justified by the group as a viable tool to attack the different segments of the Nigerian, Cameroonian, Chad and Niger communities, considered by the group as legitimate targets.

How did these developments occur? Under what conditions did these strategies evolve within the group?

The first, and perhaps the most important condition to look at is the political environment within the area when this strategy evolved. Earlier, the article had explained how the Nigerian government's response to the group's activism has been mass arrests and repression of the group. At the beginning of 2011, the Nigerian government had also deployed a coalition of a Joint Task Force (JTF) into the region. Police vans paraded in every corner of the major cities. There were constant stop and search operations, even in the most remote parts of the region. On several occasions the Nigerian government had declared state of emergencies in Bornu, Adamawa and Yobe states, the three main states that is most affected by the group's violence. Under such cases, more elaborate military actions were also devised. For example, these regulations permitted military personnel to search and confiscate the assets of any suspected individual within the emergency areas without warrant (Williams \& Guttschuss 2012: 83). In 2015, in the wake of extended BH attacks on neighbouring towns across the border, the Nigerian government also formed a military alliance with Cameroon, Chad and Niger, in order to combat the group's activities.

Although this approach has contributed to the curtailment of $\mathrm{BH}$ activities in the region, especially since the newly formed international forces are beginning to clamp down on the group on the Sambisa forest, this has been the biggest element which facilitating the evolution and escalation of different 
forms of violence in the organisation. For the organisation to continue to be able to carry out their attacks or engage with the security forces in the region under such a militarised environment, they had to devise more advanced and sophisticated means that could match those of the security force. Instead of using locally made knives and bows and arrows, they had to employ machine guns, AK-47 assault rifles and car bombs, to carry out their well-planned guerrilla attacks. These advanced weapons appeared to be the best means with which the group could still compete with the Nigerian security forces, as well as effectively carry out their attacks without being stopped. As the government further increased its militarisation approach, the group continued to improve upon these advanced methods of attack.

Having advanced their violent ideology from the Salafi thought from their previous encounters with the security forces, the group leadership did not have to look far away to find justification for this strategy. What they needed to do was to frame this strategy in a way that resonates with the activists within the group in correspondence to the political opportunities available from the environment. 'What we are facing', Yusuf would argue, 'is a new catastrophe (referring to attacks from the state security forces), like the one Allah told us: ... War against the Muslims by the Christian groups in Nigeria, with the help of the infidel government of this country' (Yusuf, quoted in Walker 2016:141). According to him, it is only when we start accepting those infidel laws, or become weak, and stop doing Jihad, will Allah allow such catastrophe to triumph. It is imperative on all Muslims therefore to fight against this, by sacrificing your souls, your homes, your cars, and your motorcycles for the sake of Allah (Yusuf, quoted in Walker 2016:141). It was also in this regard that Yusuf was fast to pronounce as 'martyrs and holy warriors' the group of $\mathrm{BH}$ activist who lost their lives in the hands of the police in 2009, when they were on their way to a funeral. When one member of the group accidentally blew himself up while making a bomb during this time, Yusuf also called him a 'martyr, and a true warrior of Islam' (Williams \& Guttschuss 2012: 31). Such framings are significant in the sense that it provided the needed ideological resource upon which mobilisation for such activism was sustained when the need to adopt such activism arose within the group.

Shekau, who led the group after they re-emerged in 2010, would consolidate this framing. He never shied away from any opportunity to remind his followers that their activism is rooted in their faith in Allah (Smith 2015: 110). This time the group had even more reason to attack the Nigerian 
government: they not only had to revenge the death of their leader and other members of the group, whom the Nigerian government had massacred unfairly from the previous wave of violence, they also had to fight with the Nigerian government, which was their biggest obstacle to achieving their goals. Correspondingly, he raised Yusuf's violent rhetoric to a new level, often urging his followers metaphorically to 'eat the heart of these infidels since they have chosen to disobey Allah' (Walker 2016: 160). For him, their mission is no longer a war between Muslims and infidels. It is mandate to 'enjoy killing unbelievers because Allah has asked them to kill them'. In the coming days (January, 2010) the group went on a killing rampage of the police and everybody whom they believed must have helped the security forces earlier, including leading politicians, religious and traditional rulers and ordinary civilians. But because by this time there was heavy security personnel presence, they had to device more sophisticated and effective means of attack. First they started with high level hit-and-run assassinations of selected individuals and high ranking JTF personnel stationed in the areas, escaping after each attack with unsuspecting motorcycles (okada, as it is called in Nigeria). They targeted the main commander of the joint task forces that were conducting the operations in the border between Nigeria and Chad. They also killed the local police Chiefs and several military personnel stationed in many parts of the region. To further demonstrate continuity with the original dismantled 2009 group, they also attacked local religious leaders and politicians who had cooperated with the police and implicated the $\mathrm{BH}$ members in the 2009 raid. They re-took houses belonging to members of the group, who either died or escaped the first raid. The people who had taken over these houses were either killed or forced to vacate them (Walker 2012:5).

The fact that Islam in general has a history, traditions and sacred scriptures which are infused with violent activism, gives such framings some credibility. Prophet Mohammed, the religion's founder was both a spiritual, as well as military leader. From $622 \mathrm{CE}$ until his death in $632 \mathrm{CE}$, the Prophet successfully consolidated his power in Medina and united the Arab feudal tribes, mostly through violence and warfare. Within that context, the religion was able to develop concepts which in that context justified violent activism, as religious and moral duty. Because of this, the religion had developed concepts which justifies violent activism. The concept of jihad for example, while referring to the obligation incumbent on all Muslims to struggle or exert (jihad) on oneself, and to follow and realise God's will, also incorporates the 
idea of activists 'to fight injustices and oppression, and engage in armed struggle to defend one's community and religion' (Esposito 2015: 1070). These kinds of concepts obviously make the religion very susceptible to be framed to justify violent activism or even martyrdom, especially when there is a conviction that the target of the attack is an enemy of the religion. Evoking such histories, the group's leadership easily considers the group's activism as a sort of religious and political moral duty, which demanded self-sacrifice and an unflinching commitment to the cause of religious transformation, greater than any individual's physical life. Under this condition, high risk activisms would seem imperative, no matter the cost.

Another important condition I consider very significant to the development of more advanced forms of violence, especially suicide bombing within the group, was the availability of resources. The Salafi orientation of the group meant that they also had an abundance of other resources such as finance, political sponsorships and assistance from both within the region and from similar brother organisations outside the country. Previous research on the group (Brigaglia 2012; 2015; Walker 2016) recounts how the organisation had either enjoyed, or at least had benefited from some sort of financial and political sponsorships in the region, and from sister networks outside the country due to its Salafi identity. Having all these resources means that the group has access to lots of funds, and networks which otherwise may not be readily available to ordinary organisations. Such resources made it easier and possible for the organisation to plan and execute certain complicated and advanced attacks, which ordinarily would have been impossible.

When I interviewed some of the members of the security forces I got the understanding that the very foundation for the disposition of suicide bombing in particular was laid by the availability of these resources, particularly in the form of co-oporation that exists between $\mathrm{BH}$ and these 'brother' groups. My respondents recount how some BH suspects admit to have been trained and collaborated with groups such as Al-Qaeda, Al-Qaeda in the Islamic Maghreb (AQIM) and Al-Shabaab, during the time the group was dismantled in 2009. According to them, most of BH's best fighters are imported from these external organisations. These relationships and mutual cooperations meant that by the time $\mathrm{BH}$ needed to step up its attacks, they have access to both the experience and the technical know-how required for the adoption of this radical form of violence that already exists within these organisations. In fact, Mohammad Abul Barra, the 29 year old who executed 
the group's first suicide bombing at a UN building in Abuja in 2009, is believed to have returned from Somalia a few days before he carried-out the attack in Abuja (Comolli 2015:105). Thus, given that such a radical method had already been developed and justified within these 'brother' groups, this strategy was at least an option to be adopted by the group. In such a militarized and hostile environment as the one where the group operated, this strategy would naturally appear as a very reasonable and efficient option to carry out such strategic attacks, which ordinarily would seem impossible to carry-out without being stopped.

\section{Conclusion}

This article set out to analyse the development and use of suicide violence in the Nigerian Islam-oriented BH. To that effect it presented a social movement theory model which charts the importance of the interplay between different dynamics both within the group and on the northern Nigerian political environment as the factors propitious for the evolution and escalation of such elements.

Mohammed Yusuf's radical ideology meant that he identified more with similar Salafi activists, and they had to split from the main old Salafi network (Ahnus Sunna \& the Izala) within the region. This lay the foundation for the formation of their own group. The consequent conflictual interaction between the new group and the old Salafi networks meant that they were with time increasingly isolated from the Islamic establishment within the region. This created a permissive political context that encouraged appeal for more radical anti-state messages. The state was forced to respond. But as the Nigerian government responded with aggressive arrests and brutal repression, the group garnered more justifications for radical jihadic and violent responses. After being dismantled in 2009, the group re-appeared in 2010. This time, they had more resources in the form of financial supports, political sponsorships and cooperation with similar oriented organisations outside the country. Faced with a more hostile political environment, these resources made it easier for the anti-system positions previously adopted by the group to gain more empirical credibility. It also meant that the group could tap into the technical know-how, the material support and the experience from similar groups needed, to adopt, carry out and sustain more advanced forms of a violent 
strategy such as suicide bombing. And as this strategy remained effective, it soon developed as the best viable option to still carry out significant attacks on the different targets of the group (within Nigeria, Cameroun, Chad and Niger).

\section{References}

Amaechi, K. 2016. Islam as a Resource for Violence in the Nigerian Boko Haram. Nordic Journal of Religion and Society 29,2:134-150.

ANONYMOUS Article 2012. The Popular Discourses of Salafi Radicalism and Counter-Radicalism in Nigeria: A Case Study of Boko Haram. Journal of Religion in Africa 42:118.

Brigaglia, A. 2012. Ja'far Mahmoud Adam, Mohammed Yusuf and Al-

Muntada Islamic Trust: Reflections on the Genesis of the Boko-Haram

Phenomenon in Nigeria. Annual Review of Islam in Africa 11: 35-44.

Brigaglia, A. 2015. The Volatility of Salafi Political Theology, the War on

Terror and the Genesis of Boko Haram. Diritto e Questioni Pubbliiche 15, 2:175-2002.

Caschetta, A.J. 2015. Does Islam have a Role in Suicide Bombings? A look at the Theological Foundations for Martyrdom. Middle East Quarterly 22, 3: 25-38.

Comolli, V. 2015. Boko-Haram: Nigeria's Islamist Insurgency. London: Hurst \& Company.

Della Porta, D. 1995. Social Movements, Political Violence and the State: A Comparative Analysis of Italy and Germany. Cambridge: Cambridge University Press.

Della Porta, D. 2009. Social Movement Studies and Political Violence. A Paper presented at the Center for Studies in Islamism and Radicalization, Aarhus University, Denmark, September 2009. Available at: http://www.cir.au.dk.pdf.filer.Hafte_4_Donatella.com. (Accessed on 25 January 2017.)

Elster, J. 2006. Motivations and Beliefs in Suicide Missions. In Gambetta, D. (ed.): Making Sense of Suicide Missions. New York: Oxford University Press.

Esposito, L.J. 2015. Islam and Political Violence. Religions 6:1067-1081.

Falola, T. 1998. Violence in Nigeria: the Crisis of Religious Politics and Secular Ideologies. Rochester: University of Rochester Press. 
Gunning, J. 2007. Hamas in Politics: Democracy, Religion, Violence. London: Hurst.

Gunning, J. 2009. Social Movement Theory and the Study of Terrorism. In Jackson, R., M. Smyth \& J. Gunning (eds.): Critical Terrorism Studies: A New Research Agenda. London: Routledge.

Gunning, J. \& I. Z. Baron 2013. Why Occupy a Square? People, Protests and Movements in the Egyptian Revolution. London: Hurst.

Hafez, M. 2004. From Marginalization to Massacres: A Political Explanation of GIA Violence in Algeria. In Wiktorowicz, Q. (ed.): Islamic Activism: A Social Movement Theory Approach. Bloomington: Indiana University Press.

Hafez, M. \& Q. Wiktorowicz. 2004. Violence as Contention in the Egyptian Islamic Movement. In Wiktorowicz, Q. (ed.): Islamic Activism: A Social Movement Theory Approach. Bloomington: Indiana University Press.

Harnischfeger, J. 2015. Boko-Haram and its Muslim Critics: Observations from Yobe State. In Pérouse de Montclos, M. (ed.): Boko Haram: Islamism, Politics, Security and the State in Nigeria. Los Angeles: Tsehai Publishers \& Distributors.

Juergensmeyer, M. 2003. Terror in the Mind of God: The Global Rise of Religious Terrorism. California: University of California Press.

Juergensmeyer, M. 2008. Global Rebellion: Religious Challenges to the Secular State - From Christian Militias to Al Qaeda. California: University of California Press.

Kassim, A. 2015. Defining and Understanding the Religious Philosophy of jihādī-Salafism and the Ideology of Boko Haram. Politics, Religion \& Ideology 16, 2-3, 173-200.

Onuoha, F. 2015. Boko Haram and Politics: From Insurgency to Terrorism. In Pérouse de Montclos, M. (ed.): Boko Haram: Islamism, Politics, Security and the State in Nigeria. Los Angeles: Tsehai Publishers \& Distributors.

Pérouse de Montclos, M. 2015. Boko Haram and Politics: From Insurgency to

Terrorism. In Pérouse de Montclos, M. (ed.): Boko Haram: Islamism, Politics, Security and the State in Nigeria. Los Angeles: Tsehai Publishers $\&$ Distributors.

Piscatori, J. 2000. Islam, Islamism and the Electoral Principle in the Middle East. Leiden: Institute for the Study of Islam and Modernity Press.

Robert, A.P. \& J.K. Fieldman. 2010. Cutting the Fuse: The Explosion of Global Suicide Terrorism and How to Stop It. Chicago and London: 
University of Chicago Press.

Roelofs, P. 2015. Framing and Blaming: Discourse Analysis of the Boko Haram Uprising, July 2009. In Pérouse de Montclos, M. (ed.): Boko Haram: Islamism, Politics, Security and the State in Nigeria. Los Angeles: Tsehai Publishers \& Distributors.

Smith, M. 2015. Boko Haram: Inside Nigeria's Unholy War. London: I.B. Tauris \& Co Ltd.

Thurston, A. 2016. 'The disease is unbelief': Boko Haram's Religious and Political Worldview. An Analysis Paper for the Brookings Project for the U.S. governmrnt Relations with the Islamic World, No.22. Available at: https://www.google.com/url?sa=t\&rct=j\&q=\&esrc=s\&source=web\&cd= 1\&ved=0ahUKEwjslvK4_avVAhWCL8AKHTPYBG4QFggnMAA\&url $=$ https $\% 3 \mathrm{~A} \% 2 \mathrm{~F} \% 2 \mathrm{Fwww}$.brookings.edu $\% 2 \mathrm{Fwp}$-content $\% 2 \mathrm{Fuploads}$ \%2F2016\%2F07\%2FBrookings-Analysis-Paper_Alex-Thurston_Final_ Web.pdf\&usg=AFQjCNGY8iURuo6NwwHvT24jyOYou5nnpQ. (Accessed on 20 April 2017).

Walker, A. 2012. What is Boko-Haram? A United State Institute of Peace Special Report. Available at: http://www.usip.org/sites/default/files/ resources/SR308.pdf.

Walker, A. 2016. Eat the Heart of the Infidel: The Harrowing of Nigeria and the Rise of Boko Haram. London: C Hurst \& Co. Ltd.

Wiktorowicz, Q. 2004. Islamic Activism and Social Movement Theory. In Wiktorowicz, Q. (ed.) Islamic Activism: A Social Movement Theory Approach. Bloomington: Indiana University Press.

Wiktorowicz, Q. 2006. Anatomy of the Salafi Movement: Studies in Conflict \& Terrorism 29:207ff.

Williams, D. \& E. Guttschuss. 2012. Spiralling Violence: Boko-Haram Attacks and Security Force Abuses in Nigeria. New York: Seven Stories Press.

Kingsley Ekene Amaechi Department of Religious Studies and Arabic Unisa kingsleyokafor06@gmail.com 